\title{
PERBEDAAN EFEK MINUMAN BERKARBONASI DENGAN MINUMAN PROBIOTIK TERHADAP PERUBAHAN \\ GAYA Z-SPRING
}

\author{
JEAN HEANSEM SARAGIH ${ }^{1}$ ZULFAN MUTTAQIN $^{2}$ LINA HADI $^{3}$ \\ FAKULTAS KEDOKTERAN GIGI UNIVERSITAS PRIMA INDONESIA \\ JL. BELANGA NO 1 MEDAN \\ e-mail :jeanhsaragih@gmail.com \\ DOI $10.35451 /$ jfm.v3i2.596
}

\begin{abstract}
The effects of soft drinks can result in changes in the resiliency of orthodontic wires usually caused by carbonated or probiotic drinks. This type of drink with a low pH in this case carbonated drinks and probiotic drinks. This is a result of carbonic acid in carbonated beverages and lactic acid bacteria in probiotic drinks that are able to release nickel (Ni) and chromium (Cr) ions. The purpose of this study was to analyze the difference in resilience of orthodontic wire $z$-spring after soaking for 8 days. Method: Experimental research by pre and post test with control group design method, samples were used as many as 27 z-spring orthodontic wires and divided into 3 groups. Resilience measurement is performed before and after immersion is measured with UTM tool Research result: In carbornation soft drinks, there is a difference in resilience on the oth day with the 4 th day $(p=0.047)$. Orthodontic wire stainless steel z- spring soaked probiotics obtained a value of $p=0.038$. Conclusion: There was a significant change in resilience between day 4 and day 8 of carbonated beverage immersion $(p=0.001)$.
\end{abstract}

Keyword: Probiotic, carbonation drink, orthodontic z-spring, resilience

\section{PENDAhuluAN}

Kondisi malposisi dari gigi seperti pada crossbite anterior dan posterior akan membuat rasa tidak nyaman. Keadaan pada saat satu atau lebih gigi mengalami malposisi lingual/labial/bukal dengan mengacu pada gigi lawannya inilah yang dinamakan Crossbite. Berdasarkan struktur yang terlibat, keadaan crossbite bila tidak diberikan perawatan dapat mengarah pada maloklusi pseudo kelas III. Kondisi crossbite dan maloklusi tersebut dapat diminimalisir, jika dilakukan perawatan ortodonti
(Jirgensone I., 2008) (Pluhari, 2011).

Alat yang sering digunakan dalam perawatan ortodonti salah satunya adalah ortodonti lepasan, yang terdiri dari komponen pasif dan aktif (Cobourne \& DiBiase, 2010).

Menurut Isaacson dkk, yang termasuk dalam komponen aktif yaitu Palatal finger springs, T Spring, Buccal canine retractor, dan Z-spring,. Zsprings merupakan pegas yang digunakan untuk memindahkan satu atau dua gigi ke arah labial. Z-springs dibuat dengan menggunakan kawat stainless steel ukuran 0,6 $\mathrm{mm}$. (Isaacson et al., 2002). 
Kekuatan yang di hasilkan dari pegas adalah berbanding langsung dengan pangkat empat diameter kawat dan berbanding terbalik dengan pangkat tiga panjang kawat. Peranti lepasan ZSpring merupakan model yang juga bisa digunakan untuk mengkoreksi crossbite. Model tersebut digunakan untuk memproklinasikan gigi insisivus, sehingga dapat menggerakkan gigi ke labial. kawat ortodonti model ini dipasang pada permukaan palatal gigi. $Z$-Spring memiliki 2 helix dengan diameter internal yang kecil (FK Universitas Brawijaya., 2014). Kekuatan daripada pegas akan semakin ringan dan semakin kelenturan apabila diameter daripada kawat yang digunakan diperkecil(Isaacson et al., 2002)

Penggunaan bahan stainless steel pada peranti ortodonti sering digunakan dikarenakan kawat stainless steel memiliki resistensi terhadap lingkungan mulut, kemudian dari segi ekonomi harganya yang lebih murah dan juga sifat daya lenting yang relatif tinggi (Kristianingsih, 2014). Bahan Stainless steel yang digunakan mengandung chromium ( $\mathrm{Cr}$ ), nikel (Ni), besi dan karbon sebagai bahan dasarnya yang akan memberikan sifat daya lenting pada kawat tersebut (O'Brien, 2002; Singh, 2007; Hedstrom, 2007).

Menurut Bishara pada tahun 2001, Kelebihan dari kawat steinless steel selain pemakaian lebih nyaman, harga lebih ekonomis dan adanya pengembangan sifat yang lebih baik daripada kawat ortodonti emas yang sebelumnya sering digunakan (Bishara, 2001).

Menurut Iflash, sifat daya lenting yang relatif tinggi merupakan keunggulan dari kawat dengan bahan stainless steel. Dimana daya lenting ini bermanfaat jika terjadi pergeseran posisi atau digerakkan atau didefleksikan ke arah tertentu. Nilai ukur daya lenting ditentukan oleh diameter, panjang kawat dan temperatur. Pemakaian kawat ortodonti pasti akan berinteraksi dengan lingkungan di dalam rongga muluti (Iflah, 2014).

Faktor lingkungan lainnya seperti kadar $\mathrm{pH}$, suhu dan lamanya terpapar suatu zat juga dapat mempengaruhi perubahan daya lenting (Gunaatmaja dan Anggi, 2011; Wirasetyawan, 2015). Keadaan tersebut dikarenakan kawat yang berada dalam rongga mulut, akan terkena paparan dari beberapa faktor seperti temperatur, kualitas dan kuantitas saliva, plak, $\mathrm{pH}$, protein, makanan dan minuman (Singh, 2008).

Efek minuman yang dapat menyebabkan perubahan daya lenting dari kawat ortodonti biasanya diakibatkan minuman berkarbonasi maupun probiotik. Hal tersebut terjadi akibat paparan pada lingkungan $\mathrm{pH}$ rendah. Sehingga terjadi pelepasan ion $\mathrm{Ni}$ dan $\mathrm{Cr}$ dari kawat yang ada dalam rongga mulut (Wasono, 2016). Temperatur dan sifat $\mathrm{pH}$ saliva akan mempengaruhi kestabilan ion logam dan akan memicu pelepasan ion $\mathrm{Ni}$ dan $\mathrm{Cr}$ di dalam rongga mulut atau disebut juga biodegradasi logam (Aryani, 2012). Minuman probiotik merupakan minuman fermentasi yang bertahan hidup dalam keasaman lambung. Hal tersebut disebabkan bakteri asam laktat yang dihasilkannya. Yakult adalah salah satu produk minuman probiotik yang sering dikonsumsi (Khimkmah, 2015). Masyarakat cenderung mengkonsumsi minuman probiotik untuk meningkatkan system imun dan juga digunakan untuk menjaga ekosistem mikroba diusus, (Rusprina \& Devi, 2008).

Terpaparnya lingkungan rongga mulut terhadap minuman dengan $\mathrm{pH}$ rendah akan mengakibatkan pelepasan 
ion logam yang terdapat pada kawat ortodonti stainless steel yang digunakan. Akibat dari pelepasan ion logam tersebut akan mengakibatkan perubahan kawat ortodonti yang dapat mempengaruhi kekuatannya (Rey Kristianingsih, et al. (2014)(Bassioni et al., 2015).

Pada penelitian Siagian, et al. (2018), efek perendaman kawat ortodonti ke dalam minuman berkarbonasi selama 13 jam hasilnya terjadi perubahan daya lenting pada perendaman kawat ortodonti stainless steel namun tidak signifikan dikarenakan pelepasan ion $\mathrm{Ni}$ dan $\mathrm{Cr}$ pada kawat tidak terlalu banyak.

Dalam penelitian Peniasi, et al. (2018), efek perendaman kawat ortodonti kedalam minuman probiotik selama 13 jam hasilnya tidak terdapat perubahan daya lenting pada kawat ortodonti lepasan stainless steel.

Pada pembuatan minuman probiotik, proses fermentasi dengan bantuan bakteri probiotik akan menghasilkan asam laktat yang mengakibatkan turunnya $\mathrm{pH}$. Bakteri probiotik mengubah glukosa menjadi asam laktat dengan $\mathrm{pH}$ lingkungan 3 sampai dengan 4,5 (Pelczar \& Chan, 2008; Rahayu \& Nurwitri, 2012) (Buckle, 1987).

Berdasarkan latar belakang diatas penulis ingin mengetahui perbedaan efek minuman berkarbonasi dengan minuman probiotik terhadap perubahan daya lenting $Z$ - Spring.

Adapun tujuan utama dari penelitian ini adalah untuk mengetahui perbedaan efek minuman berkarbonasi dengan minuman probiotik terhadap perubahan daya lenting pada peranti $Z$ Spring.

\section{BAHAN DAN METODE}

Penelitian ini diawali dengan pembuatan surat izin penelitian yang diterbitkan oleh Fakultas Kedokteran gigi Universitas Prima Indonesia. Penelitian ini menggunakan desain penelitian eksperimental laboratorium dengan jenis penelitian true eksperimental. Desain penelitian menggunakan metode pre and post test with control group design. Penelitian ini menggunakan simple random sampling terdiri dari 2 kelompok yaitu kelompok kontrol dan kelompok perlakuan.

Sampel pada penelitian ini adalah kawat alat ortodontik $Z$ - Spring dengan diameter $0,6 \mathrm{~mm}$ sebanyak 27 buah. Penelitian ini diawali dengan pemilihan Kawat klamer stainless steel ukuran 0.6 di potong sepanjang $85 \mathrm{~mm}$ sebanyak 27 buah menggunakan tang potong. Sebelumnya sudah di lakukan pengukuran menggunakan Vernier digital, kemudian di bentuk menjadi $Z$ Spring menggunakan tang ortodontik dengan membentuk setiap bagian $Z$ Spring dengan ukuran distandarisasikan

- Helix Depan : $4.3 \mathrm{~mm}$

- Helix Tengah : $2.7 \mathrm{~mm}$

- Helix Belakang : $3.8 \mathrm{~mm}$

Setelah 27 sampel Z-Spring distandarisasi tahapan selanjutnya melakukan penanaman pada akrilik sebagai basis tempat dari Z-Spring dengan menyisakan $2 \mathrm{~mm}$ jarak antara helix dan basis akrilik pada saat penanaman. Wadah tanam akrilik Diameter : $18 \mathrm{~mm}$ dan Panjang : $31 \mathrm{~mm}$

Seluruh sampel dilakukan pengukuran uji tekan sebelum diberikan perlakuan perendaman pada saliva $\mathrm{pH} \quad 6,8, \quad$ minuman berkarbornasi,dan minuman probiotik kemudia hasilnya di catat (TO).

Kemudian $27 Z$-Spring dibagi menjadi 3 kelompok perlakuan. Sebanyak 9 buah direndam dalam $\mathrm{pH}$ saliva normal, 9 buah di rendam pada 
minuman berkarbonasi dan 9 buah lagi direndam pada minuman probiotik. Kemudian seluruh sampel yang sudah direndam dimasukkan kedalam incubator bersuhu $37 \mathrm{C}$ selama 4 hari. Setelah 4 hari pindahkan kawat kedalam botol plastik dan mengukur kelentingan kawat dengan Pearson Panke Equipment $L T D$ hingga tuas berhenti turun yang artinya proses pengukuran kelentingan telah selesai dan lihat hasil pengukuran.

Uji daya lenting dilaksanakan dengan metode tri point bend test menggunakan Pearson Panke Equipment LTD dengan satuan N. Data yang diperoleh dikumpulkan berdasarkan tiap - tiap kelompok.

\section{HASIL PENELITIAN}

Penelitian ini adalah eksperimental dengan rancangan prepost test with control group design yang di laksanakan di laboratorium Fakultas teknik mesin USU dan laboratorium terpadu FKG UNPRI Medan.

Karakteristik peranti $z$ - spring berdasarkan tabel 3.1 diperoleh jumlah sampel peranti lepasan $z$ - spring pada tiap kelompok ada 9.

Pada Hari ke-4 (T1) dimana pada Saliva dengan $\mathrm{PH} 6,8$ didapatkan Mean \pm SD $27.14 \pm 8.73$, minuman berkarbonasi $27.37 \pm 1.23$ dan minuman probiotik $31.35 \pm 15.75$. Pada hari ke-8 (T2) dimana Saliva $\mathrm{pH} 6,8$ $23.54 \pm 12.43$, minuman berkarbonasi $33.02 \pm 2.79$ dan minuman probiotik $38.26 \pm 2.64$.

\begin{tabular}{lccc} 
Tabel & $\mathbf{3 . 1}$ & \multicolumn{3}{c}{ Karakteristik } & Daya \\
Lenting Subjek Penelitian & \\
\hline Karakte & $\begin{array}{c}\text { Saliva } \\
\text { PH 6,8 }\end{array}$ & $\begin{array}{c}\text { Minuman } \\
\text { Berkar } \\
\text { Bonsai }\end{array}$ & $\begin{array}{c}\text { Minuman } \\
\text { Probiotik }\end{array}$ \\
\hline & & & \\
H-O (T0) & 29.01 & 29.01 & 29.01 \\
$($ Mean \pm SD $)$ & \pm & \pm & \pm \\
& 12.55 & 12.55 & 12.55 \\
& & & \\
\hline
\end{tabular}

\begin{tabular}{cccc}
\hline $\mathrm{H}-4(\mathrm{~T} 1)$ & 27.14 & 27.37 & 31.35 \\
$($ Mean \pm SD) & \pm & \pm & \pm \\
& 8.73 & 1.23 & 15.75 \\
$\mathrm{H}-8(\mathrm{~T} 2)$ & 23.54 & 33.02 & 38.26 \\
$($ Mean \pm SD) & \pm & \pm & \pm \\
& 12.43 & 2.79 & 2.64 \\
\hline
\end{tabular}

Berdasarkan Tabel 3.2 didapatkan tidak ada perbedaan daya lenting T0-T1 saliva $\mathrm{pH} 6,8$ dengan $p=0,354$. Terdapat perbedaan yang signifikan daya lenting T0-T1 minuman berkarbonasi dengan $p=0,047$. Dan tidak terdapat perbedaan minuman probiotik dengan $p=0,297$.

Tabel 3.2 Analisa Perbedaan Hari Ke-0 dengan Hari ke-4

\begin{tabular}{llc}
\hline \multicolumn{1}{c}{ Kondisi } & $\begin{array}{c}\text { Beda Rata-rata } \\
\text { Daya Lenting }\end{array}$ & $\begin{array}{c}\boldsymbol{p}- \\
\text { value* }\end{array}$ \\
\hline T0Saliva pH 6,8 & 29.011 & 0,354 \\
T1Saliva pH 6,8 & $\begin{array}{c}27.140 \\
(-1.871)\end{array}$ & \\
& 29.011 & \\
T0Minuman & & $\mathbf{0 , 0 4 7}$ \\
Berkarbonasi & 27.369 & \\
T1Minuman & $(-1.642)$ & \\
Berkarbonasi & & \\
T0Minuman & 29.011 & 0,297 \\
$\begin{array}{l}\text { Probiotik } \\
\text { T1Minuman }\end{array}$ & 31.347 & \\
Probiotik & $(2.336)$ &
\end{tabular}

Berdasarkan Tabel 3.3 didapatkan tidak ada perbedaan daya lenting T0-T2 saliva $\mathrm{PH} 6,8$ dengan $p=0,233$. Terdapat perbedaan yang signifikan daya lenting TO-T2 minuman berkarbonasi dengan $p=0,145$. Dan tidak terdapat perbedaan daya lenting TO-T2 minuman probiotik dengan $p=0,038$.

Tabel 3.3 Analisa Perbedaan Hari Ke-0 dengan Hari ke-8

\begin{tabular}{lll}
\hline \multicolumn{1}{c}{ Kondisi } & $\begin{array}{c}\text { Beda Rata- } \\
\text { rata Daya } \\
\text { Lenting }\end{array}$ & p-value* \\
\hline T0 Normal & 29.011 & 0,233 \\
T2 Saliva pH 6,8 & $\begin{array}{l}23.539 \\
(-5472)\end{array}$ & \\
& & \\
T0 Normal & 29.011 & 0,145 \\
T2Minuman & $33.017(4.006)$ & \\
Berkarbonasi & & 0,038 \\
T0 Normal & 29.011 & \\
T2Minuman & $38.258(9.247)$ & \\
Probiotik & & \\
\hline
\end{tabular}


Mann-Whitney

\section{Berdasarkan Tabel $\quad 3.4$} didapatkan tidak ada perbedaan daya lenting T1-T2 saliva $\mathrm{pH} 6,8$ dengan $p=0,767$. Terdapat perbedaan yang signifikan daya lenting T1-T2 minuman berkarbonasi dengan $p=0,001$. Dan tidak terdapat perbedaan daya lenting TO-T2 minuman probiotik dengan $p=0,594$.

Tabel 3.4 Analisa Perbedaan Hari Ke-4 dengan Hari ke-8

\begin{tabular}{|c|c|c|}
\hline Kondisi & $\begin{array}{l}\text { Beda Rata-rata } \\
\text { Daya Lenting }\end{array}$ & p-value \\
\hline \multicolumn{3}{|l|}{ Saliva pH 6,8 } \\
\hline $\mathrm{T} 1$ & 27.140 & $0,767^{*}$ \\
\hline \multirow[t]{2}{*}{ T2 } & 23.539 & \\
\hline & $(-3.601)$ & \\
\hline \multirow{2}{*}{\multicolumn{3}{|c|}{$\begin{array}{l}\text { Minuman } \\
\text { Berkarbonasi }\end{array}$}} \\
\hline & & \\
\hline $\mathrm{T} 1$ & 27.369 & \\
\hline \multirow[t]{2}{*}{ T2 } & 33.017 & $0,001^{* *}$ \\
\hline & $(5.648)$ & \\
\hline \multirow{2}{*}{\multicolumn{3}{|c|}{$\begin{array}{l}\text { Minuman } \\
\text { Probiotik }\end{array}$}} \\
\hline & & \\
\hline $\mathrm{T} 1$ & 31.347 & \\
\hline \multirow[t]{2}{*}{$\mathrm{T} 2$} & 38.258 & $0,594^{*}$ \\
\hline & $(-6.911)$ & \\
\hline
\end{tabular}

\section{PEMBahasan}

Akibat yang ditimbulkan karena kondisi lingkungan rongga mulut terpapar minuman karbonasi dan probiotik, maka terjadi penurunan sifat fisik dan mekaniknya. (Wirasetyawan et al., 2015).

Pada penelitian ini kawat ortodontik $Z$ - spring dengan bahan stainless steel dengan larutan saliva ph 6,8 sebagai kelompok kontrol berfungsi untuk menstimulasikan adanya proses kimia di dalam rongga mulut dan pengkonsumsian minuman berkarbonasi dan probiotik sebagai kelompok perlakuan berfungsi menjadi faktor elektrokimia yang dapat memicu terjadinya perubahan daya lenting.

$$
\text { Rata-rata perbedaan daya }
$$

lenting kawat $z$-spring yang direndam saliva ph 6,8 pada hari ke-0, 4 dan 8 tidak mengalami perubahan yang jauh. Pada kawat yang direndam dengan minuman berkarbonasi mengalami perubahan rata-rata pada hari ke-8 sama halnya dengan kawat yang direndam kawat probiotik (Tabel 3.1).

Perubahan faktor lingkungan yaitu kadar $\mathrm{pH}$, temperatur dan waktu berapa lama terpapar dapat menjadi pemicu terjadinya perubahan daya lenting.

\section{Analisa hubungan daya lenting hari ke-0 dengan hari ke-4}

Pada tabel 3.2 terdapat perbedaan daya lenting kawat pada hari ke-0 dengan hari ke-4 yang direndam pada minuman berkarbonasi $(p=0,047)$ dibandingkan dengan perendaman saliva dan probiotik. Kawat ortodontik zspring terbentuk dari lapisan tipis kromium yang menjadi pelindungkawat dari korosi (Kristianingsih et al., 2014).

Pada penelitian yang dilakukan oleh William et al. (2001) dan Sumarji (2011) menyatakan bahwa kandungan kromium pada kawat ortodontik stainless steel cukup tinggi sehingga dapat menghambat terjadinya korosi. Hal ini sesuai dengan penelitian yang dilakukan oleh Hera Kim et al (1999) dari penelitiannya ditemukan bahwa lapisan oksida yang terbentuk pada kawat steinless steel masih dalam keadaan utuh dan tidak mengalami perubahan sifat.

Berdasarkan hasil penelitian yang sudah dilakukan, perendaman selama 4 hari diketahui ,mengakibatkan adanya perubahan daya lenting tetapi tidak signifikan. Hal tersebut dikarenakan pelepasan ion $\mathrm{Ni}$ dan $\mathrm{Cr}$ pada kawat tidak terlalu banyak.

\section{Analisa hubungan daya lenting hari ke-0 dengan hari ke-8}


Kawat ortodontik stainless steelz-spring yang direndam probiotik didapatkan nilai $p=0,038$. Hal ini menunjukkan terdapat perbedaan daya lenting hari ke-8 dibandingkan hari ke0 .

Kandungan asam laktat (C3H6O3) yang dihasilkan oleh bakteri pada minuman pribiotik mengakibatkan perubahan daya lenting. Penurunan kekuatan kawat ortodontik stainless ssteel z-spring akibat dari pelepasan Ion $\mathrm{Ni}$ dan $\mathrm{Cr}$ dan hal tersebut dapat memberikan dampak negatif bagi kesehatan tubuh berupa alergi, sintoksik bahkan karsinogenik bagi tubuh manusia (Situmeang, 2016).

\section{Analisa hubungan daya lenting hari ke-4 dengan hari ke-8}

Pada Pada tabel 3.4 di dapatkan perbedaan signifikan pada hari ke-4 dengan ke-8 dengan kawat yang direndam minuman berkarbonasi $(p=0,001)$. Sedangkan pada kawat yang direndam dengan minuman probiotik tidak terdapat perbedaan signifikan. Hal ini disebabkan karna kandungan kromium ( $\mathrm{Cr}$ ) pada kawat ortodontik stainless steel z-spring cukup tinggi dan memberikan perlindungan yang baik terhadap terjadinya korosi.

\section{KESIMPULAN}

5.1. Terdapat perbedaan daya lenting kawat yang direndam dengan minuman berkarbonasi pada hari ke-4 dibandingkan hari ke-0 pada minuman probiotik.

5.2.Terdapat perbedaan daya lenting kawat yang direndam dengan minuman probiotik pada hari ke-8 dibandingkan hari ke-0 dibandingkan yang lain.

5.3.Terdapat perbedaan daya lenting kawat yang direndam dengan minuman berkarbonasi pada hari ke-8 dibandingkan hari ke-4 dibandingkan minuman probiotik.

\section{DAFTARPUSTAKA}

Aryani I. 2012. Perbandingan Tingkat Ketahanan Korosi Beberapa Bracket Stainless Steel Ditinjau dari Lepasan ION $\mathrm{Cr}$ dan Ni. Tesis. Jakarta: Universitas Indonesia. hal: 6 .

Bassioni, G. et.al. Stainless steel as souceof potential hazard due to metal leaching into beverages. International Journal Electrochem. 2015. 10(1): 3792-3793.

Bishara SE. 2001. Textbook of Orthodontics. United States of America : W.B Saunders Company.

Cobourne MT and DiBiase AT. 2010. Hand Book of Orthodontics. America: Mosby Elsevier. 2010.

Dwyer J, Richard LN, Gail TR, Patricia MB, Paul MJ, Christopher TS. 2007. Prevalance and predictors of children's dietary supplements use. 97(6): 1331-1337.

Fakultas Kedokteran Universitas Brawijaya. 2014. Buku Panduan Program Profesi Dokter Gigi Ortodonsia. Malang

Gunaatmaja dan Anggi. 2011. Pengaruh Waktu Perendaman Terhadap Laju Korosi pada Baja Karbo Rendah dengan Pednambahan Ekstrak Ubi Ungu Sebagai Inhibitor Organik di Lingkungan $\mathrm{NaCl} 3,5 \%$. Universitas Indonesia: Fakultas Teknik. hal: 1

Hedstrom P. 2007. Deformation and Martensitic Phase 
Transformation in Stainless Steels. Sweden: Doctoral Thesis, 2007. p. 18-20.

Iflah DM. 2014. Perbandingan daya lenting pegas jari dengan diameter kawat $0,5 \mathrm{~mm}$ dan $0,6 \mathrm{~mm}$ pada alat ortodonti lepasan. Fakultas Kedokteran Gigi Universitas Lambung Mangkurat. Hal. 17.

Isaacson KG, Muir jd, Reed TR. 2002. Removable Orthodontics Appliances. New Delhi: Wright; 2002.p.1-39

Khimkmah N. 2015. Uji Antibakteri Susu Fermentasi Komersial Pada Bakteri Patogen. Jurnal Penelitian Saintek. 20(10): 45-51.

Kristianingsih R, Rudy J, Depi P. 2014. Analisis pezlepasan ion $\mathrm{Ni}$ dan $\mathrm{Cr}$ kawat ortodontik stainless steel yang direndam dalam minuman berkarbonasi. Artikel Ilmiah Hasil Penelitian Mahasiswa. Fakultas Kedokteran Gigi Universitas Jember (UNEJ). Hal. 3.

O'Brien J. 2002. William. Dental Materials and Their Selection ed.3rd. Quintessence Publishing, 2002. p. 275-277.

Peniasi, Wibowo D, Kurniawan FKD. 2018. Efek Perendaman Minuman Probiotik Terhadap Daya Lenting Kawat Ortodontik Lepasan Stainless Steel. Dentin. Jurnal Kedokteran Gigi. Vol II. No 1. April 2018.

Pluhari BS. 2011. Orthodontic Principles and Practice. New Delhi: Jaypee Brothers Medical Publisher(P) Ltd.

Rusprina dan Devi. 2008. Kosumsi dan persepsi manfaat minuman probiotik pada remaja putri
(Studi Kasus di SMAN 1, SMAN 2, dan SMAN 3 Kota Bogor). Program Studi Gizi Masyarakat Dan Sumber daya Keluarga. Fakultas Pertanian Institut Pertanian Bogor. Hal. 2-4.

Siagian PE, Wibowo D, Kurniawan FKD. 2018. Efek Perendaman Minuman Berkarbonasi Terhadap Daya Lenting Kawat Ortodontik Lepasan Stainless Steel.Dentin. Jurnal Kedokteran Gigi. Vol II. No 1. April 2018.

Singh G. 2007. Textbook of orthodontics 2nd ed. New Delhi: Jaypee Brothers Medical Publishers, 2007. p. 326-328.

Singht G. 2008. Textbook of Orthodontic. Malaysia: Unipress Publishing.

Situmeang, M.A. Perbedaan pelepasan ion nikeldan kromium pada beberapa merek kawatstainless steel yang direndam dalam asam cuka.Jurnal Ilmiah Farmasi. UNSRAT. 2016. 5(4):253.

Wasono N. 2016. Pelepasan Ion Nikel dan Cromium Breket Stainless Steel yang Direndam Dalam Minuman Isotonik. Unsrat; 5(1) : $158-163$.

Wirasetyawan, Iwan, Wayan Ardhana, Dyah Karunia. 2015. Pengaruh Penggunaan Air Polisher dan Jenis Kawat Terhadap Daya Lenting Kawat Busur Ortodontik Setelah Direndam Dalam Saliva Buatan. J. Ked Gi. Oktober 2015; 6(4): 347 - 353. 